\title{
PENGEMASAN PAKET EKOWISATA DI DESA LIANG NDARA, KECAMATAN MBELILING, KABUPATEN MANGGARAI BARAT, FLORES, NUSA TENGGARA TIMUR
}

\author{
Charles Bertomi \\ Ni Made Oka Karini \\ I Putu Sudana \\ Email : charlestomi@gmail.com \\ PS. S1 Industri Perjalanan Wisata \\ Fakultas Pariwisata UNUD
}

\begin{abstract}
Liang Ndara village is one of the village in Mbeliling sub-district, West Manggarai regency, Flores of East Nusa Tenggara Province. Liang Ndara village has many tourism potentials specifically regarding to the ecotourism. Free entrance fee in to those tourism places caused by unserious and less attention of the government are becoming problem, as well as Lack of human resources of people is another problem causing the potentials are not well organized yet and even it is not in a good tourism packaging.

The research aim to find out the tourism potential that can be made ecotourism packages and packaging them to become an ecotourism in Liang Ndara village. The data collection of this research is by an observation, documentation, interviewing and as well as literature. The data analysis technic used is by analysis technic of qualitative descriptive.

The results of this research showed that Liang Ndara village has three kinds of tourism potential which is in a packaging of ecotourism. Those potentials are the natural tourism potentials consist of Mbeliling Mountain, Cunca rami waterfall, Cunca Wae Kantor waterfall and Liang Niki Cave. The cultural tourism potentials are Caci dance, Compang Kafir Stone, Compang Serani statue, Batu Tiga, Hand Weaving of Songke, Farming Activities such as sopi/arak filtration, cultivating of rice field. Man made tourism potentials are information center in the village, guest house, and souvenir shops. The potentials above are packaged in to two kind of ecotourism packages they are Liang Ndara Village Tour and Mbeliling Green Forest Tour.

The suggestions are the government is supposed to put their eyes on to develop those potential exist and need to be hand in hand with the tourism actors as well as the society. The travel agencies are expected to make an interesting tourism package like ecotourism and also supposed to be together with the society to take care and survive the tourism potentials existed.
\end{abstract}

Keyword : Tourism Potential, Ecotourism, Tourism Package.

\section{PENDAHULUAN}

Nusa Tenggara Timur merupakan salah satu Provinsi yang memiliki banyak potensi wisata. Kepariwisataan di Nusa Tenggara Timur sudah ditetapkan sebagai destinasi wisata nasional dalam Masterplan Kementerian Pariwisata dan Ekonomi Kreatif pada tahun 2012. Hal ini di pertegaskan oleh Drs. Frans Leburaya dalam seminar yang digagas oleh
Forum Pemuda Nusa Tenggara Timur Penggerak Keadilan dan Perdamaian pada tahun 2012, mengatakan:

"Provinsi Nusa Tenggara Timur juga masuk dalam Koridor Bali-Nusa Tenggara sebagai Pintu Gerbang Pariwisata dan Pendukung Pangan Nasional, dalam Masterplan 
Percepatan dan Perluasan Pembangunan Ekonomi Indonesia (MP3EI)".

Kekayaan alam dan budaya yang terdapat di Nusa Tenggara Timur merupakan modal dasar dalam pengembangan industri pariwisata. Keberadaan Nusa Tenggara Timur sebagai salah satu destinasi wisata yang di minati wisatawan tidak terlepas dari potensi wisata yang dimiliki setiap daerah yang ada di Nusa Tenggara Timur.

Kabupaten Manggarai Barat yang merupakan salah satu kabupaten yang berada di ujung barat Pulau Flores memiliki potensi wisata yang patut dibanggakan terutama dengan adanya populasi komodo yang pada tahun 2012 menjadi salah satu dari tujuh keajaiban dunia. Dalam proses pengembangan pariwisata di Manggarai Barat, ada beberapa kendala yang terjadi yaitu kurangnya perhatian pemerintah terhadap potensi pariwisata desa dan keterlibatan masyarakat dalam kegiatan pariwisata sangat rendah terutama masyarakat kecil. Potensi wisata yang ada belum dikembangkan semua dan Biro Perjalanan Wisata belum mengemas daya tarik wisata yang ada dalam bentuk paket ekowisata.

Salah satu desa yang memiliki potensi dan daya tarik wisata di Kecamatan Mbeliling, Kabupaten Manggarai Barat adalah Desa Liang Ndara. Desa Liang Ndara merupakan salah satu desa penyangga pengembangan ekowisata kawasan Gunung Mbeliling yang merupakan kawasan tutupan hutan terluas di pulau Flores. Potensi wisata yang ada di Desa Liang Ndara belum dikembangkan semua, karena keterbatasan Sumber Daya Manusia yang dimiliki oleh Pemerintah Desa dan juga masyarakat. Wisatawan mengunjungi objek wisata yang terdapat di Desa Laing Ndara, tidak dikenakan biaya retribusi, karena belum adanya pengelolaan yang serius oleh pemerintah setempat.

Dengan permasalahan yang diangkat, maka penelitian ini bertujuan :

1. Mengetahui potensi wisata yang dapat dijadikan paket ekowisata di Desa Liang Ndara, Kecamatan Mbeliling, Kabupaten Manggarai Barat, Flores, Nusa Tenggara Timur.

2. Mengemas paket ekowisata di Desa Liang Ndara, Kecamatan Mbeliling, Kabupaten
Manggarai Barat, Flores, Nusa Tenggara Timur.

\section{METODE}

Penelitian dilakukan di desa Liang Ndara, Kecamatan Mbeliling, Kabupaten Manggara Barat, Flores, Nusa Tenggara Timur. Teknik pengumpulan data yang digunakan adalah observasi, wawancara, dokumentasi dan studi kepustakaan. Pada penelitian ini penentuan informannya menggunakan sampel purposif.

Penelitian ini menggunakan teknik analisis deskriptif kualitatif dengan menyajikan hasil wawancara, observasi, dan melakukan analisa terhadap potensi yang ditemukan di lapangan (Miles and Huberman) dalam Herdiansyah (2012), agar diperoleh gambaran yang jelas tentang objek yang diteliti untuk kemasan paket ekowisata di desa Liang Ndara.

\section{HASIL DAN PEMBAHASAN Potensi Wisata Alam}

Potensi wisata alam di Desa Liang Ndara meliputi: Gunung Mbeliling adalah sebuah gunung tertinggi di Kabupaten Manggarai Barat, Nusa Tenggara Timur, dengan ketinggian 1300 mdpl. Kawasan Gunung Mbeliling merupakan kawasan ekowisata yang dikembangkan oleh LSM Burung Indonesia dan LSM INDECON dengan memperdayakan masyarakat lokal, Air Terjun Cunca Rami berada di ketinggian sekitar $1200 \mathrm{mdpl}$. Air terjun ini mempunyai ketinggian sekitar $30 \mathrm{~m}$. Terdapat kolam alami yang menampung aliran air yang jatuh, Air Terjun Liang Kantor berada dibawa kaki Gunung Mbeliling dengan Jarak 1,5 km dari kantor Desa Liang Ndara. Air terjun Liang Kantor adalah salah satu air terjun yang memiliki gua yang dihiasi oleh stalaktit dan stalagmite, dan Gua Liang Niki berada di bagian barat Desa Liang Ndara dengan jarak $7.5 \mathrm{~km}$ dari kantor Desa Liang Ndara. Gua Liang Niki memiliki keunikan seperti spesies kelelawar, berbagai warna stalaktit dan stalagmit yang di bentuk dari proses air kapur yang jatuh dari atas.

\section{Potensi Wisata Budaya}

Potensi wisata budaya di Desa Liang Ndara meliputi : Tarian Caci biasa dimainkan oleh sepasang lelaki berpakaian 
tradisional, dilengkapi dengan cambuk, nggiling (tameng), koret (penangkis), panggal (penutup kepala) dan iringan genderang. Penari Caci tidak hanya menari namun juga melecutkan cambuk ke lawan sembari berpantun dan bernyanyi, Batu Compang Kafir merupakan sebuah tempat pemujaan dan penyembahan terhadap roh atau arwah leluhur bagi masyarakat Kampung Cecer, yang terbuat dari susunan batu yang berbentuk bulat (lingkar), diatas susunan batu tersebut tertata sebuah meja batu (dolmen) tempat untuk menyimpan sesajian.

Patung Compang Serani merupakan sebuah bukti atas adanya perubahan kepercayaan masyarakat Kampung Cecer, Desa Liang Ndara terhadap agama khatolik. Patung Compang Serani ini terdapat sebuah patung Bunda Maria sebagai salah satu simbol kekuatan agama Khatolik yang diletakan didalam gua beton, Batu Tiga atau sering disebut "Watu weri" oleh masyarakat Liang Ndara merupakan sebuah bukti peninggalan pemerintahan Dalu (Camat). Pada Batu Tiga dapat terlihat dengan jelas letak perkampungan dan perkebunan masyarakat Desa Liang Ndara dan masyarakat Kecamatan Sano Nggoang yang berada di bagian selatan.

Kerajinan Tangan yang dibuat oleh masyarakat di Desa Liang Ndara adalah berupa menenun kain Songke. Kain Songke merupakan kain tenunan khas masyarakat Manggarai di Flores, dan Kegiatan Pertanian berupa kegiatan di bidang persawahan maupun di ladang perkebunan. Kegiatan persawahan yang dilakukan oleh petani di Desa Liang Ndara berupa membajak sawah dan juga menanam padi hingga memanen hasil dari padi tersebut. Kegiatan perkebunan yaitu berupa menanam buah-buahan, rempahrempah dan juga mengelolah minuman beralkohol lokal seperti tuak.

\section{Potensi Wisata Buatan}

Potensi wisata buatan di Desa Liang Ndara meliputi: Pusat Informasi Wisata di Desa bagi wisatawan merupakan salah satu usaha dari pihak desa dalam memberikan informasi mengenai objek dan daya tarik yang ada di Desa Liang Ndara, Guest House atau rumah tamu merupakan salah satu usaha masyarakat yang ada di Desa Liang Ndara yang menanggapi permintaan wisatawan yang datang dan ingin menginap di Desa Liang Ndara dan Kios Cinderamata yang menjual berbagai jenis kerajinan tradisional Manggarai seperti, topi songket, kain tenun, shal / selendang, dan berbagai perhiasan dan perlengkapan tarian caci.

\section{Pengemasan Paket Ekowisata Di Desa Liang Ndara}

Paket ekowisata yang dikemas akan disajikan dalam bentuk uraian (essay style) dan bentuk grafik (graphic style). Penyusunan paket ekowisata ini akan mempertimbangkan variasi daya tarik wisata, starting point, finishing point, durasi menikmati daya tarik wisata, rute dan waktu tempuh.

a. Titik awal (starting point)

Titik awal yang digunakan dalam penyusunan paket ekowisata ini yaitu Kota Labuan Bajo sebagai pintu masuk terbesar untuk kegiatan wisata di Kabupaten Manggarai Barat.

b. Titik Akhir (finishing point)

Titik akhir dalam laporan ini, juga di Kota Labuan Bajo.

c. Waktu Tempuh antar daya tarik wisata

Penghitungan waktu tempuh dalam laporan ini yaitu perjalanan yang diasumsikan normal, tanpa adanya pemberhentian tambahan dan tanpa kerusakan kendaraan. Waktu tempuh antar daya tarik wisata selama dalam perjalanan ditentukan dengan rumus :

$$
\text { (a:b) x } 60 \text { menit }
$$

Keterangan:

$$
\begin{aligned}
\mathrm{a}= & \text { jarak (distance) } \\
\mathrm{b}= & \text { kecepatan rata-rata kendaraan } \\
& \text { (average velocity) }
\end{aligned}
$$

60 menit $=$ transformasi satuan waktu (1 jam= 60 menit), dalam penelitian ini ditetapkan kecepatan rata-rata kendaraan adalah $50 \mathrm{~km} / \mathrm{jam}$. (Suyitno,1999)

d. Durasi dalam menikmati daya tarik wisata

Dalam paket ekowisata ini, peneliti menetapkan rata-rata waktu yang dipergunakan wisatawan dalam melaksanakan acara wisata adalah $60-90$ menit. Waktu tersebut merupakan 
pelaksanaan acara wisata dengan durasi satu hari atau 8-10 jam.

Berdasarkan potensi dan daya tarik wisata yang ada di Desa Liang Ndara, penulis membuat dua kemasan paket ekowisata, yaitu sebagai berikut:

\section{Pengemasan Paket Ekowisata di Desa Liang Ndara dalam Bentuk Uraian}

Pengemasan paket ekowisata di desa Liang Ndara terdiri atas dua paket wisata yaitu full day tour (Liang Ndara Village Tour) dan 2 Days 1 Night (Mbeliling Green Forest Tour). Adapun penjelasan dari paket ekowisata yang tersebut diatas adalah sebagai berikut:

\section{Paket Wisata Liang Ndara Village Tour}

Perjalanan awal dari penyelenggaraan acara wisata, dimulai dari Labuan Bajo. Perjalanan dimulai pada pukul 08.00 WITA menuju ke air terjun Liang Wae Kantor. Kemudian menuju ke kampung Cecer untuk melihat proses penyulingan tuak menjadi arak. Perjalanan berikutnya menuju ke lokasi compang kafir.

Setelah itu, menuju ke lokasi rumah makan untuk makan siang. Setelah makan siang, dilanjutkan dengan mengunjungi compang serani. Perjalanan berikutnya menuju ke lokasi tarian adat Manggarai yaitu Tarian Caci. Setelah itu, menuju ke lokasi tenun songke. Wisatawan bisa sekaligus membeli oleh-oleh berupa kain adat (songke) yang dijual oleh para penenun kain tersebut.

Setelah selesai menonton proses penenunan kain songke dan membeli hasil tenunan, wisatawan diajak untuk kembali ke Labuan Bajo. Dalam perjalanan ke Labuan Bajo, akan terasa lengkap bila singgah beberapa saat di salah satu puncak di kampung Melo yang bisa melihat pemandangan yang indah ke Labuan Bajo dan sekaligus menikmati sunset. Acara wisata berakhir di Labuan Bajo.

\section{Paket Wisata 2D1N Mbeliling Green Forest Tour}

Pada hari pertama, berangkat dari Labuan Bajo pada pukul 08.00 WITA menuju ke lokasi Gua Kelalawar / Liang Niki. Setelah itu, melanjutkan perjalanan menuju ke kampung Melo untuk melihat dan menyaksikan secara langsung tarian tradisional masyarakat Manggarai yaitu tarian Caci.

Setelah itu, menuju ke lokasi warung lokal untuk makan siang.

Setelah makan siang, wisatawan menuju ke lokasi permulaan trekking dan apabila semuanya sudah siap, pemandu lokal akan memandu wisatawan menuju ke puncak Mbeliling. Dalam perjalanan menuju ke puncak Gunung Mbeliling, wisatawan bisa melakukan kegiatan birds watching. Pada pertengahan pendakian ke pucak Mbeliling, wisatawan bisa melihat salah satu tempat peninggalan nenek moyang masyarakat Kempo dahulu yaitu Batu Tiga yang berbentuk segitiga, kemudian setelah itu melanjutkan pendakian menuju ke puncak.

Sesampainya di puncak Mbeliling, wisatawan bisa menikmati suasana sunset dari puncak Mbeliling dengan melihat pemandangan ke arah Labuan Bajo dan ke Danau Sano Nggoang. Setelah itu, wisatawan bisa makan malam dan menyantap masakan yang telah disiapkan sambil diterangi oleh api unggun. Setelah makan malam, wisatawan bisa beristirahat.

Pada hari kedua, pagi-pagi sebelum matahari terbit, wisatawan bangun dan mempersiapkan diri untuk melihat indahnya sunrise dari puncak Mbeliling sambil melihat pemandangan yang indah ke arah Labuan Bajo dan danau Sano Nggoang. Setelah itu, menikmati sarapan yang telah disiapkan. Setelah menikmati sarapan, wisatawan langsung menuju ke air terjun Cunca Rami. Wisatawan bisa menikmati makan siang di dekat air terjun Cunca Rami.

Setelah itu melanjutkan perjalanan ke kampung Melo untuk melihat dan mengambil bagian dalam proses pengolahan persawahan para petani dengan cara membajak sawah menggunakan bantuan kerbau. Setelah itu, menuju ke lokasi tenunan kain songke. Wisatawan bisa membeli souvenir seperti kain songke ataupun hasil tenunan lainnya di tempat 
tenunan. Setelah selesai, wisatawan kembali ke Labuan Bajo dan acara wisata berakhir di Labuan Bajo.

\section{Pengemasan Paket Ekowisata di Desa Liang Ndara dalam Bentuk Grafik}

Paket ekowisata di Desa Liang Ndara dalam bentuk grafik dapat dirancang sebagai berikut:

1. Paket Wisata Liang Ndara Village Tour

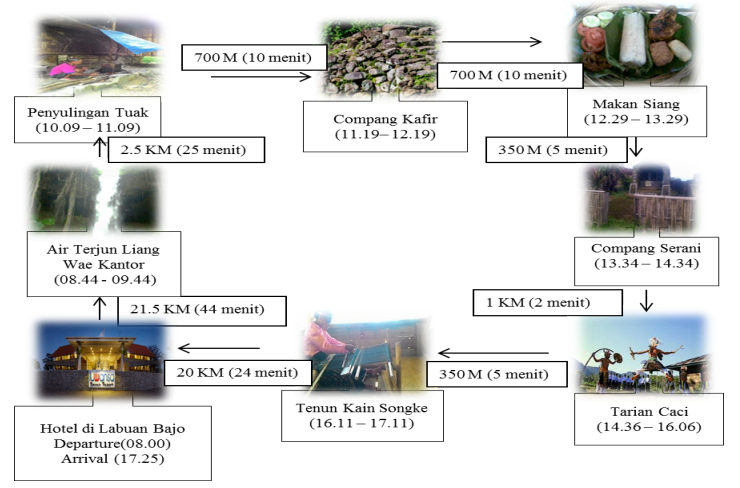

2. Paket Wisata $2 D 1 N$ Mbeliling Green Forest Tour

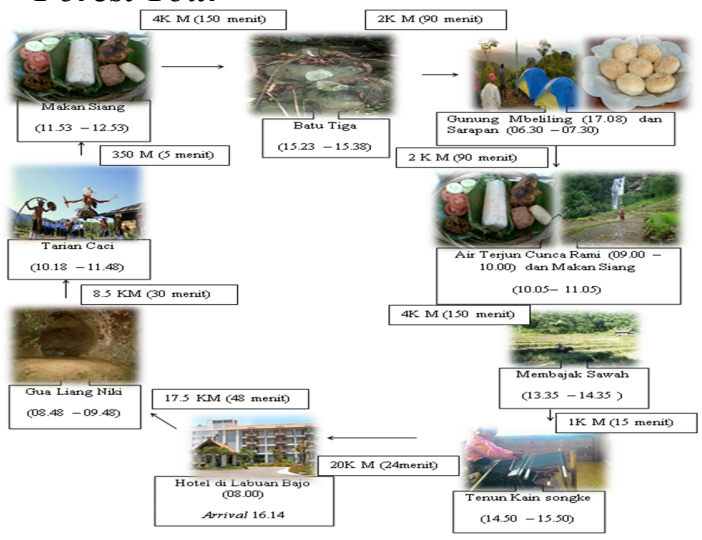

\subsection{Harga Kemasan Paket Ekowisata di Desa Liang Ndara}

Harga pada paket ekowisata di Desa Liang Ndara untuk peserta individu dan kolektif dapat dilihat pada Tabel-Tabel berikut dengan peserta kolektif sebanyak 14 orang, Agent Commission sejumlah $10 \%$, dan surcharge $20 \%$ dari harga per peserta.

\section{Paket Wisata Liang Ndara Village Tour}

\begin{tabular}{|l|c|c|c|c|c|c|}
\hline \multirow{3}{*}{ Uraian } & \multicolumn{6}{|c|}{ Jenis Kendaraan dan Jumlah Peserta } \\
\cline { 2 - 7 } & \multicolumn{3}{|c|}{ Sedan } & L 300 & \multicolumn{2}{c|}{ SMC } \\
\cline { 2 - 7 } & $\mathbf{1}$ & $\mathbf{2}$ & $\mathbf{3}$ & $\mathbf{4 - 6}$ & $7-9$ & $\mathbf{1 0 - 1 4}$ \\
\hline Jhh Biaya Tetap & 2.430 .000 & 2.430 .000 & 2.430 .000 & 2.530 .000 & 2.630 .000 & 2.780 .000 \\
\hline $\begin{array}{l}\text { Jh Biaya Tidak } \\
\text { Tetap }\end{array}$ & 70.000 & 70.000 & 70.000 & 70.000 & 70.000 & 70.000 \\
\hline $\begin{array}{l}\text { Jh Biaya per } \\
\text { Peserta }\end{array}$ & 2.500 .000 & 1.285 .000 & 880.000 & 702.500 & 445.715 & 348.000 \\
\hline Surcharge 20\% & 500.000 & 257.000 & 176.000 & 140.500 & 89.143 & 69.600 \\
\hline Nett Price & 3.000 .000 & 1.542 .000 & 1.056 .000 & 843.000 & 534.858 & 417.600 \\
\hline FOC & - & - & - & - & - & - \\
\hline Selling Price & 3.333 .334 & 1.713 .334 & 1.173 .334 & 936.667 & 594.287 & 464.000 \\
\hline
\end{tabular}

\section{Paket Wisata Mbeliling Green Forest Tour}

\begin{tabular}{|l|c|c|c|c|c|c|}
\hline \multirow{2}{*}{ Uraian } & \multicolumn{5}{|c|}{ Jenis Kendaraan dan Jumlah Peserta } \\
\cline { 2 - 7 } & \multicolumn{3}{|c|}{ Sedan } & \multicolumn{1}{c|}{ L 300 } & \multicolumn{2}{c|}{ SMC } \\
\cline { 2 - 7 } & $\mathbf{1}$ & $\mathbf{2}$ & $\mathbf{3}$ & $\mathbf{4 - 6}$ & $\mathbf{7 - 9}$ & $\mathbf{1 0 - 1 4}$ \\
\hline Jlh Biaya Tetap & 2.855 .000 & 2.855 .000 & 2.855 .000 & 3.055 .000 & 3.305 .000 & 3.555 .000 \\
\hline $\begin{array}{l}\text { Jlh Biaya Tidak } \\
\text { Tetap }\end{array}$ & 335.000 & 335.000 & 335.000 & 335.000 & 335.000 & 335.000 \\
\hline Jlh Biaya per Peserta & 3.190 .000 & 1.762 .500 & 1.286 .667 & 1.098 .750 & 807.143 & 690.500 \\
\hline Surcharge 20\% & 638.000 & 352.500 & 257.334 & 219.750 & 161.429 & 138.100 \\
\hline Nett Price & 3.828 .000 & 2.745 .000 & 1.544 .001 & 1.318 .500 & 968.572 & 828.600 \\
\hline FOC & - & - & - & - & - & - \\
\hline Selling Price & 4.253 .334 & 2.350 .000 & 1.715 .557 & 1.465 .000 & 1.076 .192 & 920.667 \\
\hline
\end{tabular}

\section{SIMPULAN DAN SARAN}

\section{Simpulan}

1. Desa Liang Ndara, memiliki potensi wisata yang terdiri atas potensi wisata alam (Gunung Mbeliling, Air terjun Cunca Rami, Air terjun Liang Wae Kantor dan Gua Liang Niki), potensi wisata budaya (Tarian Caci, Batu Tiga, Compang Kafir, Compang Serani, tenunan kain songke, dan kegiatan pertananian (membajak sawah dan penyulingan sopi / arak) ), dan potensi wisata buatan manusia (Pusat Informasi Wisata Desa, Guest House dan Kios Cinderamata).

2. Pengemasan paket ekowisata di Desa Liang Ndara dibuat berdasarkan potensi potensi wisata yang ada. Paket ekowisata yang dikemas dalam penelitian ini terdiri atas dua bentuk yaitu, bentuk uraian dan bentuk grafik dengan memiliki dua jenis paket, yaitu full day tour (Liang Ndara Village Tour) dan 2 Days 1 Night (Mbeliling Green Forest Tour). 


\section{Saran}

1. Pemerintah daerah diharapkan lebih peka dalam mengembangkan potensi - potensi pariwisata yang ada dan perlu adanya usaha pengembangan sumber daya manusia bagi masyarakat serta mengadakan kerjasama dengan pihak swasta dan melibatkan masyarakat lokal dalam proses perencanaan dan pengembangan potensi - potensi wisata yang ada.

2. Biro Perjalanan Wisata diharapkan untuk mampu membuat paket - paket wisata yang menarik perhatian wisatawan seperti paket ekowisata sehingga tidak muncul kejenuhan dari wisatawan akan paket paket wisata yang ada. Selain itu dalam membuat paket wisata, Biro Perjalanan Wisata hendaknya lebih memperhatikan keterlibatan masyarakat lokal sehingga tingkat kesejahteraan masyarakat tetap terjaga dengan baik. Para pelaku pariwisata dan masyarakat diharapkan untuk tetap menjaga kelestarian daya tarik wisata yang ada di Desa Liang Ndara.

\section{DAFTAR PUSTAKA}

Profil Desa Liang Ndara. 2014.

Saatnya Pariwisata Jadi Leading Sektor Pembangunan Nusa Tenggara Timur. Formada. 2012.

Suyitno. 1999. Perencanaan Pariwisata. Yogyakarta: Kanisius

Herdiansyah, Haris. 2012. Metode Penelitian Kualitatif Untuk Ilmu - Ilmu Sosial. Jakarta: Penerbit Salemba Humanika 